\title{
Correction to: Transdiagnostic group cognitive behaviour therapy for anxiety in bipolar disorder-a pilot feasibility and acceptability study
}

Tania Perich ${ }^{1 *}$, Philip B. Mitchell ${ }^{2}$ and Tanya Meade ${ }^{1}$

\section{Correction to: Pilot Feasibility Stud 6, 170 (2020)}

https://doi.org/10.1186/s40814-020-00719-6

Following publication of the original article [1], the authors reported an error in the affiliations. The correct affiliations are presented below.

1. School of Psychology, Western Sydney University, Sydney, Australia

2. School of Psychiatry, University of New South Wales, Sydney, Australia

The original article has been corrected.

\section{Author details}

${ }^{1}$ School of Psychology, Western Sydney University, Sydney, Australia. ${ }^{2}$ School

of Psychiatry, University of New South Wales, Sydney, Australia.

Published online: 24 November 2020

\section{Reference}

1. Perich T, Mitchell PB, Meade T. Transdiagnostic group cognitive behaviour therapy for anxiety in bipolar disorder-a pilot feasibility and acceptability study. Pilot Feasibility Stud. 2020;6:170. https://doi.org/10.1186/s40814-02000719-6.

The original article can be found online at https://doi.org/10.1186/s40814020-00719-6.

* Correspondence: t.perich@westernsydney.edu.au

${ }^{1}$ School of Psychology, Western Sydney University, Sydney, Australia

Full list of author information is available at the end of the article

(c) The Author(s). 2020 Open Access This article is licensed under a Creative Commons Attribution 4.0 International License, which permits use, sharing, adaptation, distribution and reproduction in any medium or format, as long as you give appropriate credit to the original author(s) and the source, provide a link to the Creative Commons licence, and indicate if changes were made. The images or other third party material in this article are included in the article's Creative Commons licence, unless indicated otherwise in a credit line to the material. If material is not included in the article's Creative Commons licence and your intended use is not permitted by statutory regulation or exceeds the permitted use, you will need to obtain permission directly from the copyright holder. To view a copy of this licence, visit http://creativecommons.org/licenses/by/4.0/ The Creative Commons Public Domain Dedication waiver (http://creativecommons.org/publicdomain/zero/1.0/) applies to the data made available in this article, unless otherwise stated in a credit line to the data. 